\title{
The Priority of the Church's Ministry during a Pandemic
}

\author{
Ardi Sastrohartoyo ${ }^{1 *}$, Rubin Adi Abraham², Jantje Haans ${ }^{3}$, Tjahyadi Chandra ${ }^{4}$ \\ ${ }^{1}$ Indonesian Mission Institute (IMI) Australia \\ 2, 3, ${ }^{4}$ Sekolah Tinggi Teologi Kharisma Bandung, Indonesia \\ Email: 1*ardi.sastrohartoyo@gmail.com, ${ }^{2}$ rubinabraham2@gmail.com, 3jantje_haans@yahoo.co.id, \\ ${ }^{4}$ chuangtjah@gmail.com
}

\begin{abstract}
The global COVID-19 pandemic has caused churches to change their worship patterns from meeting at church buildings to virtual worship at home to prevent transmission of the virus and comply with the health protocols set by the local governments. This study aims to determine the priority of the pastoral ministry during the COVID-19 pandemic and explore new strategies to be adopted analyze and examine the functions of the church, especially with regards to how the church responds previously during the pandemic and determines the priority of the church's ministry to continue to do the Great Commission and the Great Commandment amid the COVID-19 pandemic. This study uses the descriptive qualitative method by researching relevant literature using Biblical perspective. Based on this study, we recommend that churches to embrace digital online technology for digital evangelism to effectively reach, connect and engage with many people who are more connecting to social media platforms. Online church is an effective tool for evangelism and missiology to extend the reach and enable the spread of the Gospel worldwide in the digital era.
\end{abstract}

Key Words: Worship, Pastoral Ministry, COVID-19 Pandemic, Online Church, Digital Era

\begin{abstract}
ABSTRAK: Pandemi global COVID-19 telah menyebabkan gereja-gereja untuk mengubah pola ibadahnya dari yang dilakukan di gedung gereja kepada pola ibadah virtual di rumah, sebagai upaya untuk mencegah transmisi virus dan mengikuti protokol-protokol kesehatan yang telah ditetapkan oleh pemerintah setempat. Penelitian ini bertujuan untuk menganalisa dan menggali apa yang menjadi fungsi dari gereja, khususnya berkaitan dengan pertanyaan apa yang menjadi sikap gereja sebelumnya ketika diperhadapkan dengan pandemi dan untuk mengetahui akan apa yang menjadi prioritas pelayanan gereja untuk tetap dapat melakukan apa yang menjadi Perintah Utama dan Amanat Agung di masa COVID-19 pandemi. Metode yang digunakan bersifat kualitatif deskriptif melalui penelitian terhadap berbagai literatur yang relevan dengan menggunakan perspektif Alkitab. Berdasarkan penelitian ini, kami merekomendasikan gerejagereja untuk memanfaatkan teknologi digital untuk dapat menjangkau, terhubung dan terlibat secara efektif dengan banyak orang yang sekarang menggunakan platform media sosial. Gereja online adalah alat yang efektif untuk melakukan pekabaran Injil dan misiologi untuk memperluas jangkauan penyebaran Injil ke seluruh dunia di era digital.
\end{abstract}

Kata Kunci: Ibadah, Pelayanan Gereja, Pandemi COVID-19, Gereja Online, Era Digital

Article History: Submitted: 30 Oktober $2020 \quad$ Revised: 5 Juli $2021 \quad$ Published: 27 Juli 2021

\section{INTRODUCTION}

Coronavirus disease (also called Covid-19) is an infectious disease caused by coronavirus 2 (SARSCoV-2) virus strain that was first reported in December 2019 in Wuhan city, Hubei province, China (Wu et al., 2020). It spread to every part of the world within months of its outbreak. As of April 2021, the virus has infected more than 132 million people and caused deaths of over 2.89 million worldwide (World Health Organization, 2021).

As part of the efforts to break the chain of transmission of the virus, governments throughout the world, including Indonesia and Australia have closed their borders and imposed heavy-handed lockdown measures by suspending schools and transport, and forcing the immediate closure of many 
businesses, major public events and religious gatherings at places of worship (Boyd, 2020; Hadiwardoyo, 2020; Hall, 2020; Nasution et al., 2020). Undoubtedly, this pandemic has impacted religion in various ways including the cancellation of In-person worship services of various faiths, along with pilgrimages, ceremonies, and festivals. These have been replaced with worship at home using supportive Livestream technology (Boyd, 2020; Conley, 2020). This was and sometimes is not strictly followed by some Christian leaders as they believe that following the government's lockdown rules is considered a lack of faith (Asa, 2020). This has led to a rapid spread of the Coronavirus in many places, including Georgetown Christ Church in Washington DC, USA (LifeSite, 2020) and Shincheonji Church of Jesus in South Korea (H. J. Kim et al., 2020). Gatherings at the latter church caused the spread and infection of the general population in South Korea (S. Kim et al., 2020).

Churches worldwide must look for the best ways to continue church services without facilitating person-to-person transmission of the disease and operating within the government guidelines. Most of the churches, both in Indonesia and abroad by April 2020 were not able to hold worship meetings in church buildings. They had to shift their religious activities from church buildings to live streaming technology via radios, televisions, and several online platforms available such as Zoom, YouTube or social media. Most of the churches in Melbourne had to implement their Online services by 15 April 2020 to continue their worship at home; this includes Australia for Christ Church Indonesia, which converts into $100 \%$ Online for the first time since its establishment 14 years ago (Sundjaja 2020). A pastor may be uncomfortable in leading the online worship and preaching without seeing the congregation in the church buildings (Tirtha, 2020). Members of the congregations may also feel that they miss seeing the presence of other members.

\section{Statement of the Problem: The Biggest Challenge for Churches at this Time}

This study explores how pastors perform their pastoral ministry to their church members during the Covid-19 pandemic lockdown. The purpose of this paper is to evaluate and gain important new insights on the priority of the pastoral ministry during the Covid-19 pandemic.

This study explores the effects of the Covid19 pandemic lockdown of churches, especially Indonesian churches in Australia. Covid-19 must not hinder worldwide church to continue preaching the gospel and fulfilling the Great Commission of Christ (Matthew 28) without accidentally spreading the disease in church gatherings.

This paper is different from the other studies conducted previously: Simanjuntak (2020) and Tambunan (2020) have researched the relevance of worship together in church buildings after the pandemic ends. Siahaan (2017) has also conducted a study focusing on digitalization issues with online church services, and the importance of actualizing the gift of the ministry in the digital era. This was then later developed by Hartono (2018), who emphasized the Great Commission of Christ based on Matthew 28:18 to provide answers to the challenges emerging in this age of globalization and the advancement of information technology. In contrast to the emphasis of this previous research, this paper focuses on what the priority of church ministries should be during the global Covid-19 pandemic including in Indonesia and Australia. New strategies are needed to be adopted by church leaders so that social distancing is not accompanied by spiritual distancing that makes members of the congregation further away from God.

\section{METHOD}

The descriptive qualitative method (Rahmadi, 2011) was used in this study by researching relevant literature using Biblical perspective. The problem of Covid-19 was not discussed in a medical framework, except for the existence of a social problem caused by the spread of this deadly virus, since most of the 
people who live in Indonesia and Australia have a basic understanding of Covid-19 as an epidemic of a viral disease that is infectious and has caused deaths of millions of people worldwide.

Literature research methodology was used in this study, which aims to gain an indepth understanding of the field of research in question by collecting data from books, magazines, articles, dictionaries, word studies, and electronic media. In order to achieve good results in this research, the documentation method was used by collecting valid data related to this journal's research. The main source was taken from the Bible because the Bible is a collection of tested truths. The use of various related tools such as notes, books, newspapers, magazines, and the Internet is necessary for this study. Finally, after collecting valid data, the data was then analyzed, and conclusions were then drawn inductively (Hadi, 2014) to get a comprehensive finding from the study that had already been completed.

\section{RESULTS AND DISCUSSIONS}

\section{Redefining the Meaning of 'Fellowship' and 'The Essence of Worship' in The Digital Era}

In the age of digitalization, another theological challenge is to redefine what the fellowship 'koinonia' means, which in the Bible, fellowship in the church means the physical gathering of believers. In the New Testament, the word 'house' is used 274 times, in the original Greek language 'oikos or 'oikia' means house, building, or dwelling place.

When the armies of the Babylonian empire destroyed God's temple built by King Solomon, this changed the pattern of worship for the Israelites and they were forced to rethink the essence of worship for hundreds of years, since in the center of worship was at the temple in Jerusalem. The essence of worship shifted from the physical building (temple in Jerusalem) to obedience to the Word and no longer focused on the sacrificial offerings as the Israelites did in the Old Testament (1 Sam. 15:22).
Many churches are resistant to change and adopt new technologies such as the electronic Bible in the year 2000 in which was initially rejected by church members at that time, but now almost all church members have an electronic Bible on their smartphones (Hutchings, 2015). The General Treasurer of the Indonesian Bethel Church said that even in the development of sophisticated technological advancement, digital technology simply cannot replace all of the direct physical relationships of the church fellowships and the holy sacraments that are carried out at church (i.e. such as the blessings of marriage, baptism and praise and worship) simply because our relationship with God cannot be digitalized (Saragih, 2016). The issue of technological advancement was also debated by the church in the 90s when television broadcasts were filled with sermons. There was a concern that the congregation would no longer come to the church to worship together, but that fear did not materialize. Churches as a result of this fear not coming true, began to post sermon online.

\section{Theological View of Worship and the Function of the Church}

During constantly changing times and with rapidly changing technology, churches should be able to move dynamically, actively, and positively under the guidance of the Holy Spirit to carry out the vision and mission to do God's will in the world (Mat. 28:18-20, 1 Pet. 4:2, 1 Joh. 2:17). The church needs to understand its five vocations: Worship (Liturgia), Fellowship (Koinonia), Testimony (Marturial Kerugma), Discipleship (Didaskalia), and Ministry (Diakonia). These are derived from the Great Commandment (Mat. 22:37-40) and the Great Commission (Mat. 28:19-20) (I. P. A. Darmawan, 2019; Sembiring, 2020).

The church's first priority to proclaim the gospel of salvation to all the nations does not mean that we should ignore serving our communities or fellow humanity (D. Darmawan, 2019). It is the gospel preached and lived that impacts humanity and 
society with power. Service without proclamation, or vice versa, is useless. Although, in reality, it is difficult (or perhaps impossible) to separate preaching and service, the church must practice both. If we feed the hungry today but fail to preach the gospel of salvation and no one turns to Christ, they will ultimately die in their sins. Many para-church organisations like the Red Cross, Salvation Army, and World Vision can care for the poor, clothe the naked and feed the hungry; but only the church (or churches) can proclaim the good news of salvation in Christ Jesus. (Bryson et al., 2020; Silitonga, 2020). These church activities must continue during this global pandemic even when everyone has to stay in lockdown.

In the first century, gospel spread across the ancient world through Rome's highway systems. Today's version of Rome's highway system is Zoom, Facebook, YouTube, and many internet-based tools that are allowing Christians to reach more people than ever before. Bible teaching will still need to continue online, although it can be awkward to preach into a camera rather than a room full of faces. But good Bible teaching is good Bible teaching, and the church needs to embrace technology as part of its calling in these difficult times. Church leaders can also help build relationships with local hospitals, clinics, food pantries, shelters, and mobilize the church's congregation to help with mobile donations, drop-offs, and online orders that can be done without having physical contact with others.

\section{The Church Exemplifies the Merciful Actions of the Lord Jesus Christ}

Actions of Love are not only carried out within one's own family, but also to others who need help. Jesus set the ultimate example in John 13:15. Jesus is the Son of God, the Most High King and Lord of Lords (Dan. 7:11-14), and He served others to the point of giving His life. Jesus did not come to be served but to serve and He led by serving and loved by serving (Mat. 20:28). Jesus lived a life of humility and throughout His ministry on earth, Jesus healed the sick and spent time with those whom no one else cared to spend time with.

The parable of the good Samaritan written in the Gospel of Luke 10:3-37 shows how the church should initiate compassion ministry to others, meeting the felt needs. Jesus in His ministry on earth also not only taught and spread the gospel alone but $\mathrm{He}$ also acted in mercy repeatedly by healing the sick: the blinds were given sight (Luke 18:35), the deaf heard (Mark 7:31), the lame walked (Luk. 5:26), and the dead came back to life (Mrk. 5:43, Luk. 7:17). Jesus also fed five thousand people (Mat. 14:20, Mrk. 6:43), four thousand people (Mat. 15:37, Mrk. 8:8).

According to the Christian faith, we are to do good to one another because God has already done good to us (1 Joh. 4:19), especially by sending His only Son to atone for our sins. The Apostle Paul encouraged the Church to have the same servant attitude of Christ Jesus (Phil. 2:5-8). If God's own Son, the creator of heaven and earth, the Eternal One, stepped out of eternity to take on a human body to serve to the point of humiliation, suffering and death, we as the Church must follow His example in our service of one another.

The disciples debated on more than one occasion which one of them was the greatest and should receive the most honor in the God's kingdom; yet Jesus took the position of greatest humility by serving others, washing His disciples' feet, and even dying on a cross (Joh. 13:12-15). Jesus also teaches us a parable that describes acts of mercy in Matthew 25:37-40. Jesus demands our personal involvement in caring for others' needs (Is. 58:7). These are simple acts freely given and freely received that Christians have no excuse to neglect toward those who have deep needs. In fact, when God's people do good deeds for the church and others, they are doinggood works that God has prepared for all His people, including becoming the Light and Salt of the World so that others will see these good deeds and glorify the Father who is in Heaven (Eph. 2:10, Mat. 5:13-16). 


\section{Worst Pandemics in Global History - What Church Can Learn?}

Throughout the course of history, disease outbreaks have ravaged humanity and Christians have shown sacrifice and devotion to others, even outside the Christian community. The church leaders are needed now more than ever to inspire and calm the congregation's fear in facing the difficult challenges in this Covid-19 pandemic. Global pandemics caused by an outbreak of this disease have occurred repeatedly throughout human history: The Athens Pandemic in 430 BC, the Plague of Justinian in 541$542 \mathrm{M}$, the Black Death in 1346-1353, the Great Plague of London in 1665, the Cholera plague in 1820, the Bubonic Plaque in 1904, and the Spanish Flu in 1920, the latter being one of the deadliest pandemics recorded in history that resulted in deaths of millions of people (Newman, 2020; Trilla et al., 2008).

More recently, other viruses have appeared such as avian flu, swine flu, MERS flu, and the SARS flu. However, these types of flu were not as fast spreading and contagious as Covid-19, which has spread to almost all countries worldwide and resulted in millions of deaths, but also the global economy and financial crisis followed by the economic recession and the hunger crisis in many countries globally. The Spanish flu outbreak that occured about 100 years ago was a forgotten pandemic until recently. It was an H1N1 virus that was transmitted from birds to humans at the time of World War I, and infected more than 500 million people (over one-third of the human population at that time), including a few world figures such as President Woodrow Wilson and British Prime Minister Llyod George, and killed approximately more than 50 million people (Taubenberger \& Morens, 2006). Now, the Covid-19 has undoubtedly made many people recall the Spanish flu and other disease outbreaks that happened previously. The experience of dealing with this pandemic seems quite foreign to the modern church as congregations lack the psychological and cultural supports to be able to know how cope with this crisis. Many people feel the fear of death and uncertainty until vaccines or antibodies have been fully developed and widely distributed to stop the virus' transmission and save humanity from the current Covid-19 pandemic.

The church should respond amidst this global pandemic by starting with the well-known teachings of Jesus Christ in Luke 6:31 and Mark 12:31 to follow His example by loving our enemies and granting enemies the same respect and rights Christ-followers want for yourself. Love means action, and one way to put love to work is to take the initiative in meeting specific needs not only for people we trust but doing so even to those who dislike or plan to hurt us. When Christians were faced with the Antoine plague during the Roman empire in the second century, the body of Christ took social actions by caring for the sick and offering a spiritual model, which ultimately resulted in the spread of Christianity at that time. The plague of Cyprian, a suspected Ebola-related disease, is also responsible for Christianity's rapid growth in Rome in the third century. (Trilla et al., 2008).

The church will need to continue taking care of and provide for every need of those greatly affected by the Covid-19 pandemic. When the second wave of the Bubonic Plague pandemic hit the city of Wittenberg, Germany, Martin Luther, a professor of Theology and the founder of the Protestant movement, responded by not leaving the congregation to protect himself and his family from the deadly plague. However, he decided to stay to continue to serve and take care of the sick, his action results in the death of his daughter, Elizabeth, who passed away due to the plague. Martin Luther states that the epidemic did not make him cancel his duties, but rather turned his duties into a way of the cross, by which Christians must be prepared to die (Gehrz, n.d.; Hancock, 2020). The motive for personal hygiene and sanitation does not only appear in self-care but also in the ethics of service to others.

It is undeniable that the Covid-19 pandemic has changed the pattern of meeting procedures and also the pattern of worship for millions of Christians worldwide. Many pastors and church leaders around 
the world are tasked to think creatively when collective worship is no longer allowed to be performed conventionally in church buildings or places of worship. One way this has played out is to allow the members of congregations to continue to carry out worship activities at their homes or online.

\section{Technology Advancement in The Digital Era - Think Digital}

The development of digital technology is a reality that cannot be avoided by any person or organization living today in the context of globalization and the life of a digital society that interacts via the Internet and social media (Markman, 2012). This is now a phenomenon of modern life. The current advancement of digital technology has brought humans into a new world that cannot be separated from electronic devices in the wave of the digital era. Radios and televisions were in existence before the 1990s and television was more frequently used and available for long-distance communication to a mass of people located at diverse geographical locations globally. In the current situation where Covid-19 is spreading throughout the world, this online technology greatly helps everyone communicate face-toface using supporting devices such as computers, smartphones, or other devices that must be connected to the Internet (Pakpahan \& Fitriani, 2020).

In the past, many traditional churches refused to exist online and chose not to use digital technology as a medium to support or assist the delivery of pastoral ministry at church. Through the development and advancement of different technologies, many things have been made things easier in our lives, including communication, education, and transportation. Indonesia is ranked the $4^{\text {th }}$ largest country that utilizes social media in the world. There are estimated around 95.2 million people (35\%) of the total population 267 million people in Indonesia have used Facebook in 2020 either via computers or mobile phones/smartphones. This is due to the increasing number of the middle class who are consuming and also influenced by freedom in technology and communication. (Jayani, 2019; Pratnyawan, 2019).

The existence of the global Covid-19 pandemic has greatly accelerated the adoption of online technology in the digital era (Bao et al., 2020; Schilirò, 2020). Digital technology can be a powerful tool for the church that can help effective churches in their mission to share the Gospel. The church is no longer limited by territorial and geographic boundaries because online technology has provided the freedom to express the form of service to meet the needs of today's digital society (Howard, 2010). In a contactless world, most interactions must take place virtually without physical contact; therefore, adopting digital online is the only way to survive. The church needs to embrace technological advancement and be innovative, flexible, and sensitive to meet the needs of the people by integrating and accommodating the In-person church services with virtual/ online ministries. The church may assign additional resources responsible for implementing and running Online service by recruiting members who can operate video cameras and video editing, upgrading the church's websites for the congregation members to give tithes and offerings online, worship online from home, and much more. The church may also need to select one or multiple live streaming platforms to broadcast the Sunday Service and hold other activities such as Cell Group, Bible study classes using Zoom meeting or YouTube Premiere platforms or re-streaming on social media such as Instagram and Facebook. Other church activities such as corporate prayer, pastoral care, and Sunday school services for children can be conducted online (Halim et al., 2020). The entire church's organizational structure will need to be designed to support the implementation and delivery of online church services for the next year(s) during this lockdown until the restrictions around COVID19 are lifted or enough of the world's population has been successfully vaccinated. 
Digital is the New Normal - Strategy for Church Ministry to Invest in Online Service

According to Pastor How from Heart of God Church in Singapore, church worship and pastoral ministries cannot return to normal following the end of the Covid-19 pandemic, because even when conditions return to normal, things will no longer be the same. This is called the 'New Normal' where people must remain productive amidst the Covid-19 pandemic until vaccines are deemed effective in controlling the virus outbreak worldwide (How, 2020). Based on some research conducted on worship services during the Covid-19 pandemic, although traditional congregations of person-to-person worship are generally more loyal to their (physical) home church, online church viewers (digital) have a polygamous character. They tend to watch several different church services. If the local churches do not provide options for online services, they will drink spiritually from other wells (Asa, 2020). Live streaming church services, on the other hand, have become a choice for anyone to listen to their sermon/teachings and allow churches to be a blessing for other people outside a particular church who are watching the online services including Sunday services, prayer groups, cell groups, and webinars that can also be accessed online. Even though we all want to return to normal now, church members have already become accustomed to the state of the online church and interactions between members that are very close digitally but very far away physically. The global Covid-19 pandemic has made the Online church service shift from a side concern to a primary concern. Thus, the church must build and strengthen both its in-person and online services. Like how the commercial business world has physical stores and online/digital stores, the two church services are aimed at different target audiences: (1) In-person service is aimed at Christians who live within the vicinity of the church building, whereas (2) Online service is available to non-church and non-Christians for gospel evangelism where the church can grow in quantity through the introduction of the church and
Christianity. It is available for those who are physically unable to attend In-person church due to the distance and inability to travel, i.e., no vehicles, illness. The Online church can also be an effective tool that can be used by the congregation to invite their friends and family to attend the church services - this provides an opportunity to see what the church is like.

The church will also need to focus on providing Non-Downloadable Content (NDC) to avoid cannibalization of the In-person service (How, 2020). NDC are things that cannot be downloaded or obtained online. However, they can only be received physically by attending In-person services such as the presence of the Holy Spirit, face-to-face pastoral ministry, laying of hands (blessings), fellowship with other members (friendship and an atmosphere of togetherness of meeting with other church members), the involvement of the congregation in ministry, a sense of belonging, the warmth atmosphere/ energy in the church, direct discipleship in real life and many more. The Heart of God Experience (HOCGx) Church in Singapore has a strong 5 pillars model consisting of Home, Character, Mobilisation, Culture \& Atmosphere, and Young \& Young Adults Revivals. All of these cannot be found/ downloaded online. The HOG church Singapore has now grown to 10,000 members who joined the Easter morning service on various social media platforms (How, 2020).

With the many available choices of Online services on live streaming media from churches all around the world, this has caused an information overload (Peabody, 1965). Local small churches may be feeling under pressure to compete with Megachurches such as Hillsong, Planet Shakers, etc. to get the attention of their local church's members. This can be overcome by customizing the sermon materials to be specific and relatable to the context of our local church congregations to encourage them to tune in and join their online church in the area. For example, if the key message is about 'prayer', it can be further confined to suit the context of the local group of demographics to 'how to pray for entre- 
preneurs in Melbourne who are facing a financial crisis during this Covid-19 pandemic'.

\section{Extending Gospel Preaching and Church Planting Services Online}

With the existence of social restrictions to prevent the spread of the Covid-19 pandemic, the church should not be discouraged, disappointed, angry, or frustrated because the congregation is no longer able to meet and do worship together at the place of worship. Instead, the church should use this as a great opportunity for evangelism and mission that are not limited to geographical locations. The church can move freely to reach other nations (which previously unreachable with traditional person-to-person ministry) and lead many nations to God so that it can trigger an explosion of Christianity in the world., the "virtual" church has functions and benefits as a place of worship and evangelism (Widjaja et al., 2020).

The concept of the 'home church' can be found in the worship patterns of the early church in Acts 2:46 where Apostle Paul initially started his ministry from one house to another - this became the initial center of evangelism in the cities that existed to serve/minister and build up the body of Christ in the Early Church from Phillipi (Acts 16:15), Thessalonica (Acts 17:7), Corinth (Acts 18:1) and Caesarea (Acts 21:8) to do evangelism and missionary work. The missionary strategy of Apostle Paul by church planting in these major cities was so effective that within only two years, all the inhabitants in the province of Asia minor (this area covers modern-day Turkey) heard the gospel, both Jews and Greeks (Acts 19:10).

Social media today is enabling many ordinary Christians to have one-on-one conversations about their faith with non-believers, which contributes to the spread the Gospel, similarly how Apostle Paul had used the home churches previously in the apostolic era (Foltz \& Foltz, 2003; Hutahaean et al., 2020). The use of digital media to share the gospel of Jesus Christ is important today, as it is the most effective way to reach large masses of people today. Especially during
Covid-19 lockdown, more people are gathering online and do most of their communication through online. Digital evangelism can be an effective tool in the New Normal digitalisation era to effectively reach all age groups, including retirees and senior citizens, as they are connecting more and more to social media platforms and watching livestreams of gospel preaching at all times of the day. Church pastors and leaders need to strengthen the missionaries through discipleship to build up, equip and empower them to be effective in spreading the gospel.

Social media offers much more avenues for congregations to actively engage with sermons of church activities, or continuing discussions through out the week by sharing the sermon links and posting this online on their social media platforms. Church leaders need to understand that engaging their followers online is important. The best social media strategy is the one that brings the most engagement by posting video content that leads to discussion, write posts that invite a response and ensure to engage in conversations when they happen. The most effective churches on social media use it as an extension of their ministry. It is a vehicle available to extend the reach, reinforce your values and engage with the congregations and to reach people to lead them to know Jesus as Christ and Savior. Church pastors and leaders need to think of the social media presence as an extension of the ministry, so be dedicated to it and remember every click, like and follow represents a real person with a real need to draw closer to the Lord. (Hutahaean et al., 2020; Widjaja, 2018; Widjaja et al., 2020).

\section{CONCLUSION}

The initial aims of this study are to determine the priority of the pastoral ministry during the Covid19 pandemic and explore new strategies to be adopted by pastors and Christian Leaders, so that physical distancing is not also accompanied by spiritual distancing that makes members of the congregation further away from God. From the discussion and results of the study we can draw several conclusions: 
First, the Covid-19 pandemic that the church is experiencing now is one of many pandemics that have happened in human history and will happen again approximately every 100 years. The church must focus on serving others (diakonia) based on love by imitating the work of Christ Jesus. Second, Pastors and Christian Leaders should embrace the use of the Internet and other technological tools in their pastoral ministry as Covid-19 pandemic has accelerated the adoption of online technology in this digital era. The entire church's organizational structure will need to be designed to support the implementation and delivery of both in-person and online services, without sacrificing the in-person service, by providing things that are not digital and cannot be accessed online (Non-Downloadable Content).

\section{REFERENCES}

Asa, Si. (2020). How COVID-19 changes Christianity. The Jakarta Post.

Bao, H., Cao, B., Xiong, Y., \& Tang, W. (2020). Digital Media's Role in the COVID-19 Pandemic. JMIR MHealth and UHealth. https://doi.org/10.2196/20156

Boyd, S. (2020). Victoria declares state of disaster and increases restrictions to stage four. The Canberra Times.

Bryson, J. R., Andres, L., \& Davies, A. (2020). COVID-19, Virtual Church Services and a New Temporary Geography of Home. Tijdschrift Voor Economische En Sociale Geografie, 111(3), 360-372. https://doi.org/10.1111/tesg.12436

Conley, B. (2020). Ministry During COVID-19: How do we, knowing that we are susceptible to the COVID-19 virus, imitate Jesus in offering a healing touch? Priest.

Darmawan, D. (2019). Model Diakonia Gereja Di Tengah Pandemi COVID-19. Journal of Chemical Information and Modeling.

Darmawan, I. P. A. (2019). Jadikanlah Murid: Tugas Pemuridan Gereja Menurut Matius 28:18-20. Evangelikal: Jurnal Teologi Injili Dan
Third, the use of social media for digital evangelism can be an effective tool to effectively reach all age groups, the concept of home or cell churches has been used previously and it was very effective to enable the spread of the Gospel in the apostolic era in the first century to increase health and significant church's growth.

The use of digital technology is not something that eliminates the essence of worship, because in truth, the church is not about the buildings, but is a fellowship of believers built based on the faith in Jesus Christ. This is back to the real meaning of worship that is all about the obedience and growth of faith in personal knowledge of Jesus Christ to carry out the the Great Commission of Christ.

Pembinaan Warga Jemaat, 3(2), 144-153. https://journal.sttsimpson.ac.id/index.php/EJTI/ article/view/138

Foltz, F., \& Foltz, F. (2003). Religion on the internet: Community and virtual existence. Bulletin of Science, Technology and Society. https://doi.org/10.1177/0270467603256085

Gehrz, C. (n.d.). About Martin Luther's Letter: Whether Christians Should Flee the Plague.

Hadi, S. (2014). Metodologi Research. In Universitas Gajah Madha.

Hadiwardoyo, W. (2020). Kerugian Ekonomi Nasional Akibat Pandemi Covid-19. Baskara Journal of Business and Enterpreneurship.

Halim, H. P., Hermanto, Y. P., \& Abraham, R. A. (2020). Pastoral Care for Sunday School Children of Indonesian Church in Australia During Pandemic. International Journal of Research and Innovation in Social Science, 04(12).

https://doi.org/10.47772/ijriss.2020.41223

Hall, D. E. (2020). We Can Do Better: Why Pastoral Care Visitation to Hospitals is Essential, Especially in Times of Crisis. Journal of Religion and Health. 
https://doi.org/10.1007/s10943-020-01072-X

Hancock, A. (2020). Calculated risks: Exploring plague ethics with luther and barth. Acta Theologica, $40(2)$ https://doi.org/10.18820/23099089/actat.v40i2. 04

How, T. S. (2020). Optimizing Online Service Without Cannibalizing In-Person Services. Outreach Magazine, Heart of God Church Singapore.

Howard, R. G. (2010). Enacting a virtual "ekklesia": Online Christian fundamentalism as vernacular religion. New Media and Society. https://doi.org/10.1177/1461444809342765

Hutahaean, H., Silalahi, B. S., \& Simanjuntak, L. Z. (2020). Spiritualitas Pandemik: Tinjauan Fenomenologi Ibadah Di Rumah. Evangelikal: Jurnal Teologi Injili Dan Pembinaan Warga Jemaat, $4(2)$, 234. https://doi.org/10.46445/ejti.v4i2.270

Hutchings, T. (2015). E-Reading and the Christian Bible. Studies in Religion/Sciences Religieuses. https://doi.org/10.1177/0008429815610607

Jayani, D. H. (2019). Berapa Pengguna Internet di Indonesia? Databoks.

Kim, H. J., Hwang, H. S., Choi, Y. H., Song, H. Y., Park, J. S., Yun, C. Y., \& Ryu, S. (2020). The delay in confirming COVID-19 Cases Linked to a Religious Group in Korea. Journal of Preventive Medicine and Public Health. https://doi.org/10.3961/JPMPH.20.088

Kim, S., Jeong, Y. D., Byun, J. H., Cho, G., Park, A., Jung, J. H., Roh, Y., Choi, S., Muhammad, I. M., \& Jung, I. H. (2020). Evaluation of COVID19 epidemic outbreak caused by temporal contact-increase in South Korea. International Journal of Infectious Diseases. https://doi.org/10.1016/j.ijid.2020.05.036

LifeSite. (2020). Priests, bishop reveal rashness in banning Communion on tongue in response to coronavirus. LifeSite.

Markman, K. M. (2012). A Networked Self: Identity, Community and Culture on Social Network
Sites. New Media \& Society. https://doi.org/10.1177/1461444812453432

Muncy, J. A. (1997). Market Differentiation Strategies for Church Growth. Journal of Ministry Marketing \& Management. https://doi.org/10.1300/j093v02n02_01

Nasution, D. A. D., Erlina, E., \& Muda, I. (2020). Dampak Pandemi COVID-19 terhadap Perekonomian Indonesia. Jurnal Benefita. https://doi.org/10.22216/jbe.v5i2.5313

Newman, T. (2020). Comparing COVID-19 with previous pandemics. Medical News Today.

Pakpahan, R., \& Fitriani, Y. (2020). Analisa Pemanfaatan Teknologi Informasi Dalam Pembelajaran Jarak Jauh Di Tengah Pandemi Virus Corona Covid-19. JISAMAR (Journal of Information System, Applied, Management, Accounting and Researh).

Peabody, R. L. (1965). BERTRAM M. GROSS. The Managing of Organizations: The Administrative Struggle, Vols. I and II. Pp. xx, 971. New York: Free Press of Glencoe, 1964. \$19.95. The ANNALS of the American Academy of Political and Social Science. https://doi.org/10.1177/000271626536000140

Pratnyawan, A. (2019). Pengguna Instagram dan Facebook Indonesia Terbesar ke-4 di Dunia. In Suara.Com.

Rahmadi. (2011). Pengantar Metodologi Penelitian. In Journal of Chemical Information and Modeling.

Saragih, M. (2016). Dalam Gelombang Era Digital. Berita Oikumene, Persekutuan Gereja-Gereja Di Indonesia (PGI).

Schilirò, D. (2020). Towards digital globalization and the Covid-19 challenge. International Journal of Business Management and Economic Research(IJBMER).

Sembiring, J. F. (2020). Gereja dan Diakonia. Jurnal Teologi Pondok Daud.

Silitonga, R. (2020). Respon Gereja Atas Pandemik Corona Virus Desease 2019 dan Ibadah Di Rumah. Manna Rafflesia, 6(2), 86-111. 
https://doi.org/10.38091/man_raf.v6i2.125

Simanjuntak, I. F., Simanjuntak, R., \& Ditakristi, A. H. V. (2020). Analisis tentang Relevansi Ibadah Gereja Pascapandemi Covid-19. DIEGESIS: Jurnal Teologi Kharismatika, 3(1), 13-25. https://ojs.sttrealbatam.ac.id/index.php/diegesis /article/view/63

Sundjaja, Arman (Australia for Christ Church, R. A. (2020). Kebaktian Online Gereja Australia for Christ Church Indonesia.

Tambunan, F. (2020). Analisis Dasar Teologi terhadap Pelaksanaan Ibadah Online Pascapandemi Covid-19. EPIGRAPHE: Jurnal Teologi Dan Pelayanan Kristiani, 4(2), 154. https://doi.org/10.33991/epigraphe.v4i2.210

Taubenberger, J. K., \& Morens, D. M. (2006). 1918 Influenza: the Mother of All Pandemics. Emerging Infectious Diseases. https://doi.org/10.3201/eid1201.050979

Tirtha, C. (Indonesian C. C. (2020). ICC has gone online.

Trilla, A., Trilla, G., \& Daer, C. (2008). The 1918 "Spanish Flu" in Spain. In Clinical Infectious Diseases. https://doi.org/10.1086/590567

Widjaja, F. I. (2018). Misiologi Antara Teori, Fakta dan Pengalaman (1st Editio). Andi Offset.

Widjaja, F. I., Marisi, C. G., Togatorop, T. M. T., \& Hartono, H. (2020). Menstimulasi Praktik Gereja Rumah di tengah Pandemi Covid-19. Kurios (Jurnal Teologi Dan Pendidikan Agama Kristen), 6(1), 127-139. https://doi.org/10.30995/kur.v6i1.166

World Health Organization. (2020). WHO Coronavirus Disease (COVID-19) Dashboard. World Health Organization.

Wu, Y. C., Chen, C. S., \& Chan, Y. J. (2020). The outbreak of COVID-19: An overview. In Journal of the Chinese Medical Association. https://doi.org/10.1097/JCMA.0000000000000 270 